\title{
METHOD OF MEASUREMENT AND REDUCTION OF THE ELECTROMAGNETIC DISTURBANCES INDUCTED BY SWITCHING SURGES IN LV CIRCUITS
}

\section{Patryk Dariusz Wąsik}

Wrocław University of Science and Technology, Faculty of Electronics, Photonics and Microsystems, Chair of Electronic and Photonic Metrology, Wrocław, Poland

Abstract. This paper presents a fast, reliable and portable method for measuring electromagnetic disturbances in LV circuits (overcurrent circuit breakers). The experiment was carried out under conditions reflecting the real measurement environment. The method was verified and confirmed by a series of measurements with passive components reducing the disturbance. The results of the measurements made it possible to obtain suitable EMI reduction solutions, which can be used to protect commutators or end consumers. The results obtained make it possible to apply the method to measurements of multichannel circuit breakers, in which measuring the turn-on time of individual channels is important for the correct operation of the devices.

Keywords: EMI, circuit breaker, fast measurement method, LV circuits

\section{METODA POMIARU I REDUKCJI ZABURZEŃ ELEKTROMAGNETYCZNYCH INDUKOWANYCH PRZEZ PRZEPIECIA LĄCZENIOWE W OBWODACH NN}

Streszczenie. W artykule przedstawiono szybka, niezawodna i przenośna metodę pomiaru zaburzeń elektromagnetycznych $w$ obwodach nN (wyłączniki nadpradowe). Eksperyment przeprowadzono $w$ warunkach odzwierciedlajacych rzeczywiste środowisko pomiarowe. Metoda została zweryfikowana $i$ potwierdzona seria pomiarów z elementami pasywnymi redukujacymi zaburzenia. Wyniki pomiarów pozwolity na uzyskanie odpowiednich rozwiąań redukcji zaburzeń elektromagnetycznych. Dobrane komponenty moga być wykorzystane do ochrony komutatorów lub odbiorników końcowych. Uzyskane wyniki pozwalają na zastosowanie metody do pomiarów wyłączników wielobiegunowych, w których pomiar czasu załączenia poszczególnych biegunów jest istotny dla poprawnej pracy urządzen.

Slowa kluczowe: EMI, wyłącznik nadprądowy, szybka metoda pomiarowa, obwody nN

\section{Introduction}

Correct operation, reliability of electrical equipment and apparatus has a direct impact on the protection systems performance. Factors that have a significant influence on the equipment operation are electromagnetic disturbances, which can be emitted into the environment, inducing safety and reliability problems [1]. The common phenomenon nature of the electromagnetic interference determines the need for research on devices in terms of meeting the defined standards adapted to a given device type, and also for research on metrological solutions which can be used not only in laboratory conditions.

One of the protection systems for electrical installations is overcurrent circuit breakers, commonly used in household electrical grids. Commutators used in installation, power solutions, and industrial are used to obtain the desired circuitry in the electrical installation in order to enable the operation of power consumers. The result of an overcurrent switch (commutator) work, apart from switching on the circuit, is a generation of high frequency electromagnetic noise and overvoltage spikes $[2,5]$. The most frequently generated noise are groups of impulses and are characterized by high irregularity of amplitude, duration, and repetition period $[4,11,12]$.

The electric current conduction through the contact in a commutator is a very complex mechanism [8] and depends on the material of the contacts, the contact surface, the connectors contact force etc $[3,12]$. The contact surface is micro-porous [3], because that current flow does not occur on the whole contact surface, but only on a small part of it. The connection resistance is determined not only by the actual surface used for conduction, but also by the resistance of the film on the contact surface [3]. During switching action, the contacts can bounce off each other repeatedly, causing interruption of the flowing current and the formation of an electric arc [7, 9].

Once the arc is ignited, the contact resistance as such ceases to exist $[2,7]$. The erosion of the contact material as a result of the arc is determined by the energy released in the arc path when the contact "bounces" [2, 3]. However, the discharge duration is short enough to prevent the formation of a thermally balanced plasma, and the arc is not permanent and does not permanently erode the contact. Due to the length of such an arc, this phenomenon can be called sparking.
Electromagnetic disturbances are generated during the switching system operation [2,7]. The interference level depends on the value of switched voltage, technical commutator condition, and properties of the circuit (load). In general, the signal spectrum can reach up to $50 \mathrm{MHz}$ and sometimes above this frequency. Regarding the frequency spectrum and propagation conditions, most of the disturbance spectrum in the range up to $10 \mathrm{MHz}$. The generated disturbance may interfere with the circuit to which the breaker is connected $[8,10]$.

Measurements of circuit breakers - apart from laboratory tests - take place in switchgear, which limits the choice of measuring tools. Compact solutions of possibly high accuracy class should be chosen. The proposal measurement methodology should create a model of physical phenomena that occurs in the tested object. The information obtained will allow not only to visualize the phenomena but also to further improve the measurement process and to create an explicit model of behavior, due to which - for a given apparatus - it will be possible to create a solution to the problem. The described measurement methodology is consistent with the article [6].

Due to the short duration of the described switching phenomenon, the required mobility of the solution, the use of a spectrum analyzer may give inaccurate results - scanning the required frequency range takes longer, or the initial bandwidth is too low [15]. A fast, reliable method, giving results while the commutator is running, is to use a precision portable oscilloscope and obtain a frequency spectrum.

This paper is divided into two main parts: chapter 1 describes the test methodology and measurement results of the selected commutator. Chapter 2 contains possible solutions based on popular passive components and verification of the proposed method. The solutions are arranged on the basis of the proposal test result, next proposal - next test result, etc.

\section{Measurement methodology}

The assumption for the proposed methodology outlined at the end of introduction is simplicity. It can be release by construction of the model bench that reflects the actual measurement conditions as closely as possible. The created model is shown in Fig. 1. The measuring device of the circuit is PicoScope 3405D oscilloscope [14]. The probes used for measurements are the 
included TA375, set to the $\mathrm{x} 10$ operating variant. Additionally, for measurements of current and possible detection of radiated emission, a current probe was used, marked TA189 [16].

The power supply of the system was realized in a safe way (against electric shock). Impulse power supply with an output voltage of $12 \mathrm{~V}$ and maximum current $45 \mathrm{~A}$ was used for generating direct current. $300 \mathrm{VA}$ mains transformer generating the alternating current - output voltage is $12 \mathrm{~V}$. The load characteristic is shown in the Fig. 2.

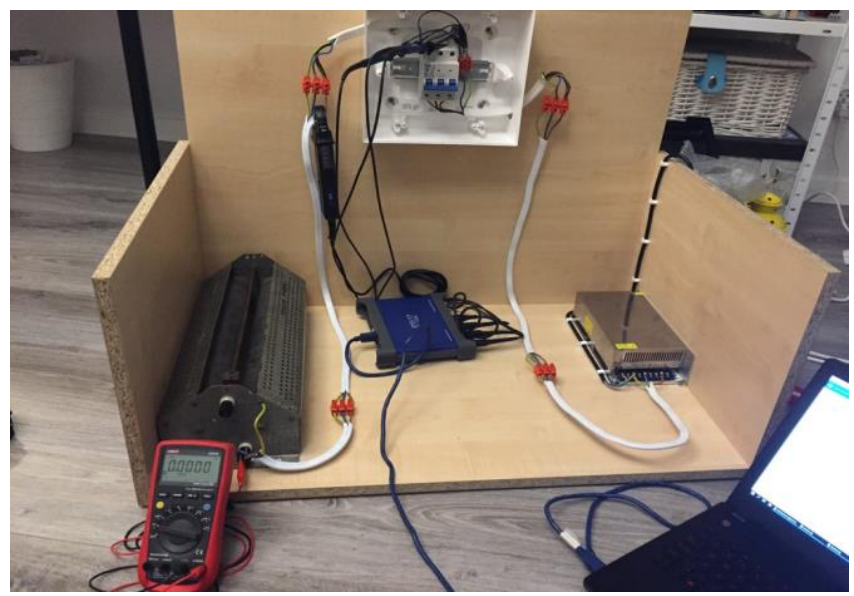

Fig. 1. Test bench model

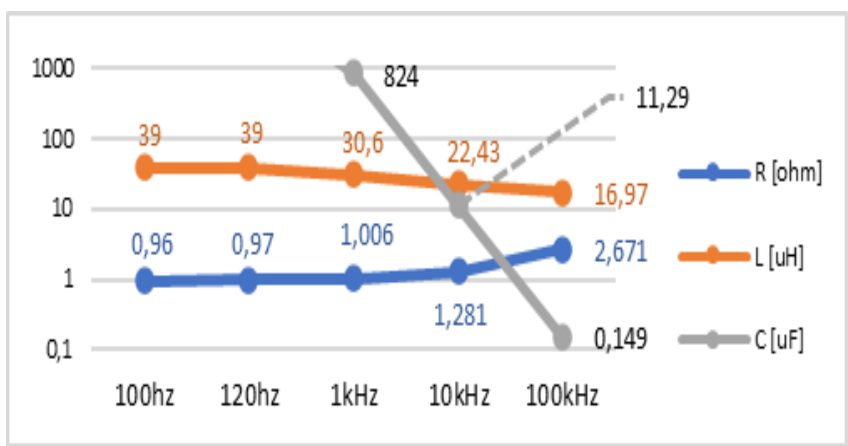

Fig. 2. Load characteristic used in circuit

Circuit breaker selection was based on measurements of 16 circuit breakers with different tripping classes and the number of poles. Similar correlations were observed between the frequencies of disturbances at different currents. Disturbances were in the form of broadband noise, mostly composed of voltage pulses of different duration. The difference was in the power of the noise described. Therefore, the commutator most similar to the average results has been chosen. Characteristics of the selected switch [13]. The measurement results are described below. The first one presented is the measurement of the circuit breaker at $12 \mathrm{~V} \mathrm{DC}$.

The graphs from figure 3 contain in each case an increased number of voltage peaks, in each measurement attempt a disturbance was also observed in the circuit of current measurement realized with the use of current probe (current clamps) - the phenomena may suggest the generation of radiated disturbances as well. The switching time was $85.25 \mu \mathrm{s}$, the maximum noise voltage reached the value of $19.48 \mathrm{~V}$. The circuit is characterized by a noise band, from 0 to $15 \mathrm{MHz}$, with a peak at $4.2 \mathrm{MHz}$. Low power disturbances were also observed in the 35 to $49 \mathrm{MHz}$ range.
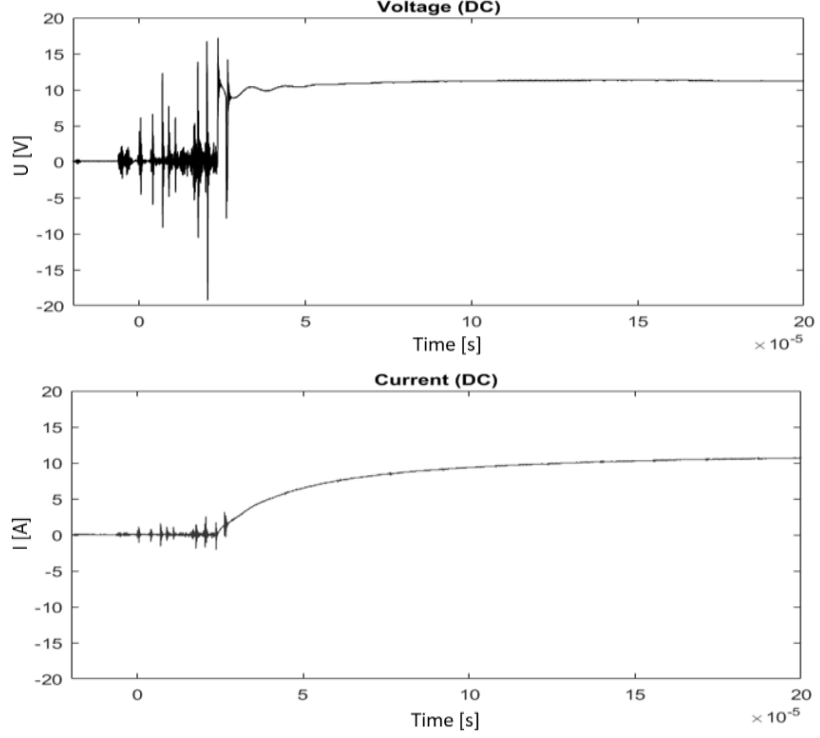

Fig. 3. Time waveforms from commutator test-direct current
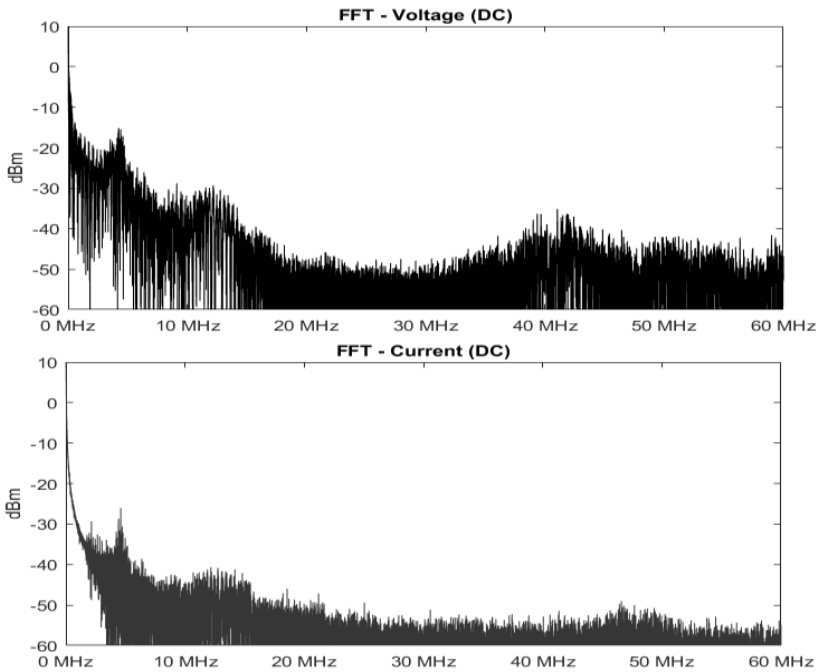

Fig. 4. Time waveforms from commutator test-direct current

Next measurement option - alternating current.
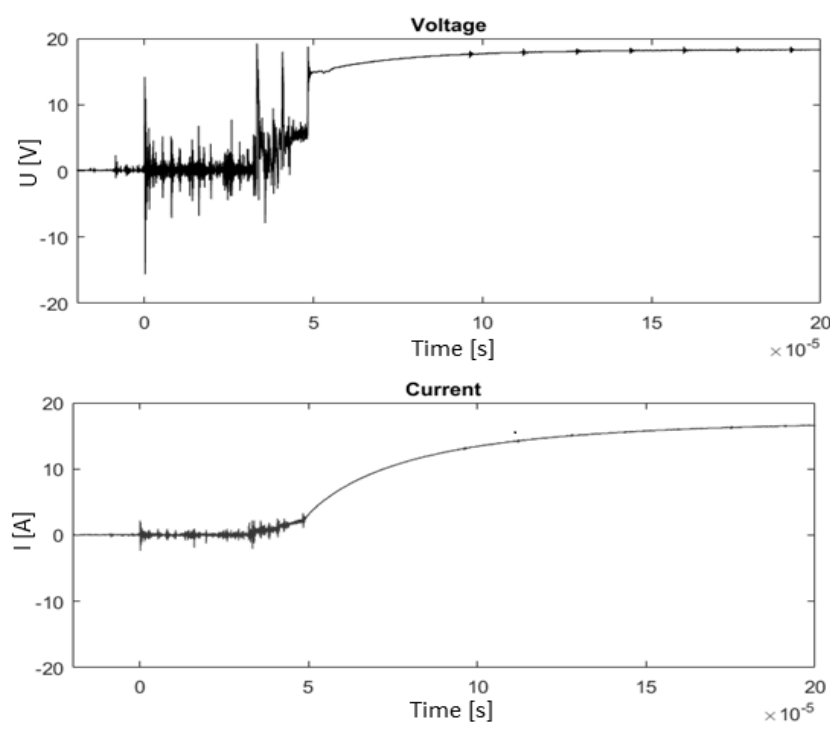

Fig. 5. Time waveforms from commutator test-alternating current 

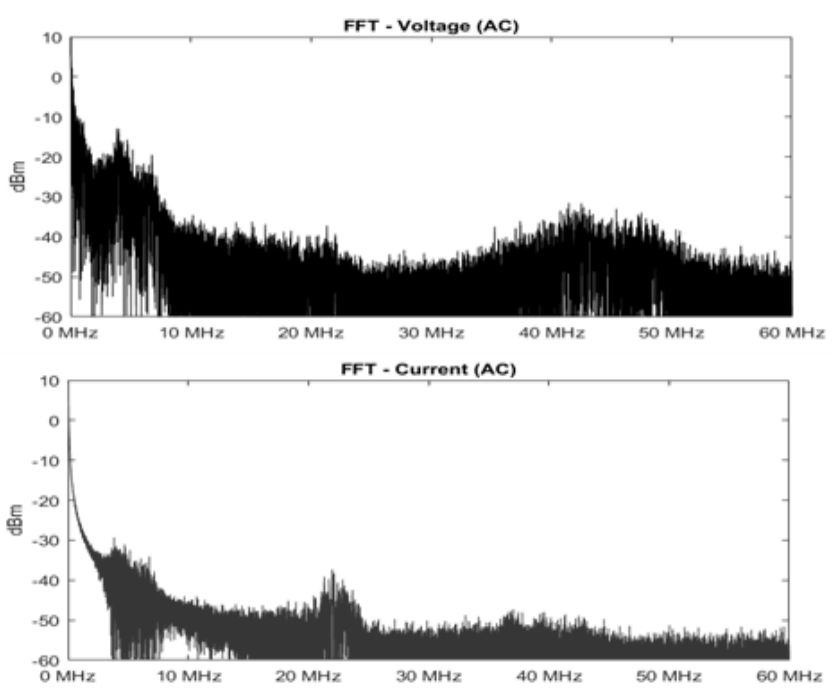

Fig. 6. Observed disturbance spectrum for alternating current

In the case of an AC supply to the commutator, it can be observed that the oscillograms are less disturbed (compare Fig. 3 and Fig. 5), which is as expected. The switch-on time was $337.8 \mu$ s, the maximum noise voltage was $19.54 \mathrm{~V}$.

The frequency analysis shown in Figure 6 partially confirms the conclusions drawn from the oscillograms regarding the significant energy of the observed disturbances, with the highest value reached around $4 \mathrm{MHz}$. The noise is broadband, occurring in the ranges from 0 to $11 \mathrm{MHz}$ and again, from 33 to $52 \mathrm{MHz}$.

\section{Elimination methods of electromagnetic disturbances}

Verification of the measurement method requires a series of measurements.

The use of popular and common EMI-reducing elements can confirm the validity of the proposed solution. During the measurements of circuit breakers several disturbances occurring in the circuits were observed, however it is difficult to clearly identify the dominant type of disturbances existing in the circuit. The most characteristic are disturbances in the form of voltage peaks, very similar to the defined test parameters from IEC 61000:4:4 (fast transients). The first proposed method is to connect a gas discharge tube in parallel to the commutator. Attempt of the use of the three popular elements is shown on Fig. 7.

The oscillograms from Fig. 7 clearly show that the variant with three leads has the lowest overvoltage values, the duration of which has been almost halved. One of the possible reasons for this situation is the use of the third lead, which can be connected directly to the protective earth, so that possible disturbances will be discharged into the mentioned circuit. For a more detailed comparative analysis, transformations of the recorded emission spectrums into frequency waveforms were performed.

The frequency analysis from Fig. 8 confirms the observations, highlighting a reduction in the frequency range of the disturbances - from 0 to $13.2 \mathrm{MHz}$ without protection, from 0 to $5.4 \mathrm{MHz}$ in the best variant. The peak value in both cases is at $4.1 \mathrm{MHz}$, while the energy carried at this frequency has decreased by about $5 \mathrm{dBm}$.

Another component tested against overvoltage was a $7 \mathrm{~mm}$ diameter disk varistor from Würth Elektronik ( $\mathrm{p} / \mathrm{n}$ : 820571406). The oscillograms and frequency analysis of this solution is shown on Fig. 9 and Fig. 10.

The varistor has significantly reduced the short voltage pulses energy, which is also confirmed by the frequency analysis (see Fig. 10). With this type of protection, there was no peaks in the frequency domain and the significantly reduced broadband noise was limited to $6.2 \mathrm{MHz}$. Comparing the results with the gas discharge element, the tested varistor definitely reduced the disturbances and overvoltage values.

Subsequently, it was decided to use a filter consisting of a capacitor and an inductor, in series connection. During tests on this protection type, it was found that the capacitance had a significant effect on the system performance, compared to the inductance value of the coil. The measurement results are shown on Fig. 11 and Fig. 12.
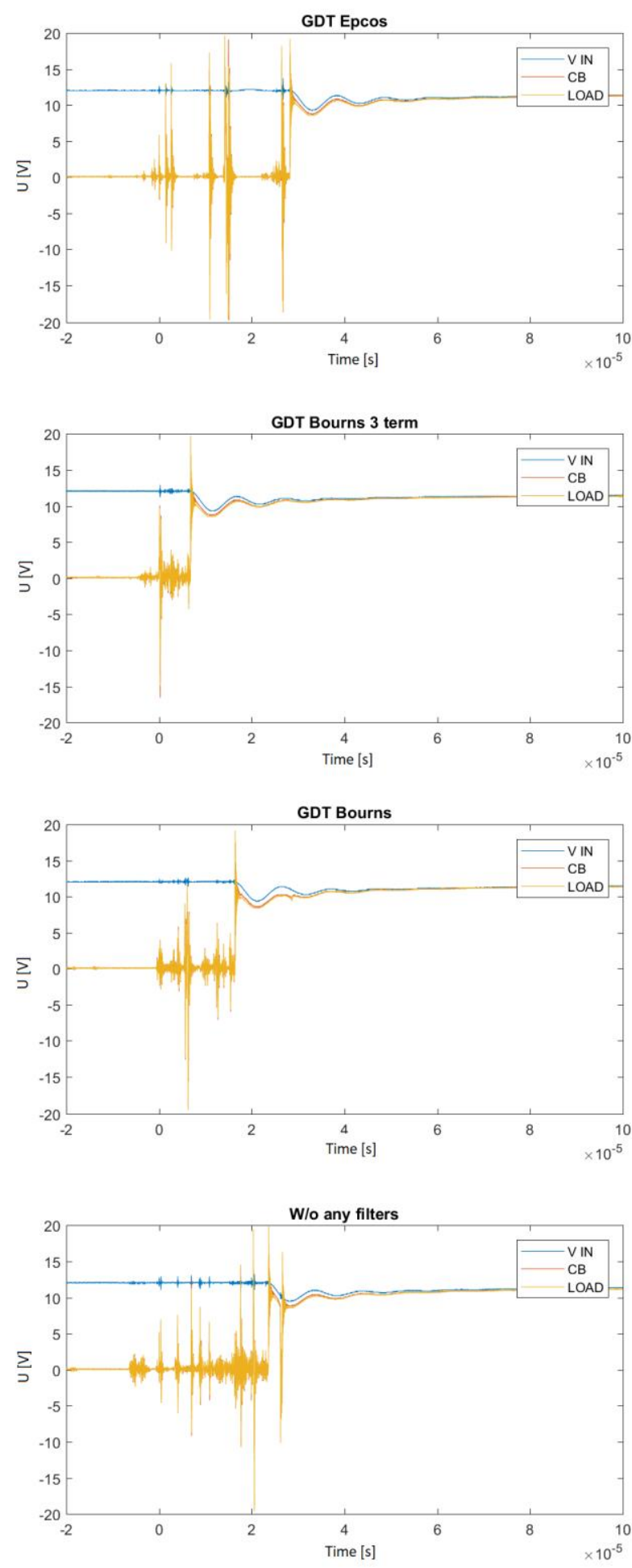

Fig. 7. Results of the analysis of observed disturbances using GDT [Epcos SA24500, Bourns 2020-15T-C2LF (3-term version) and 2031-15T-SM-RPLF + result without any filters 

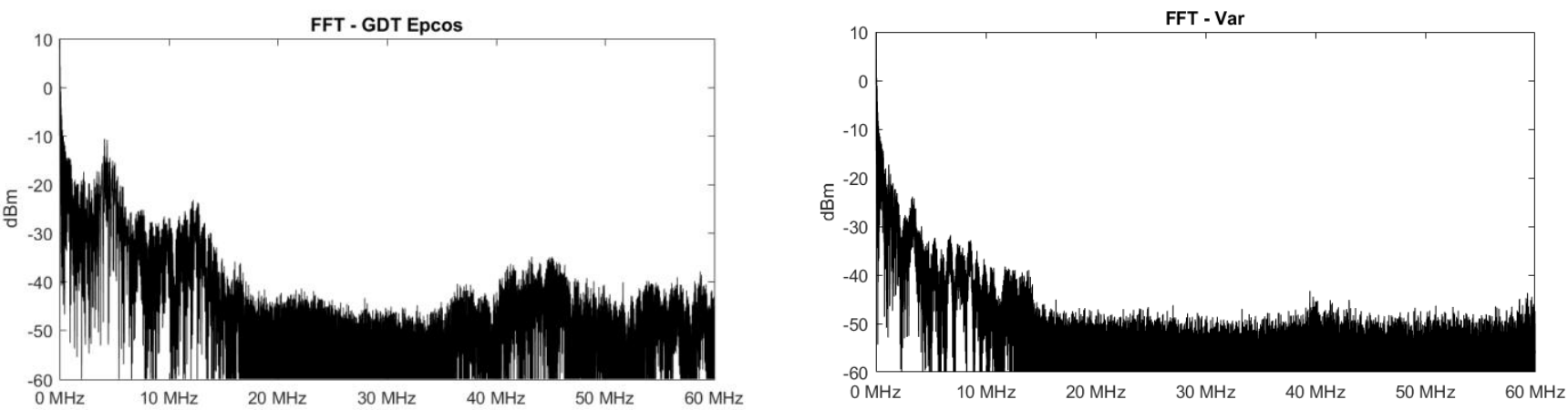

Fig. 10. Frequency analysis at the commutator - varistor

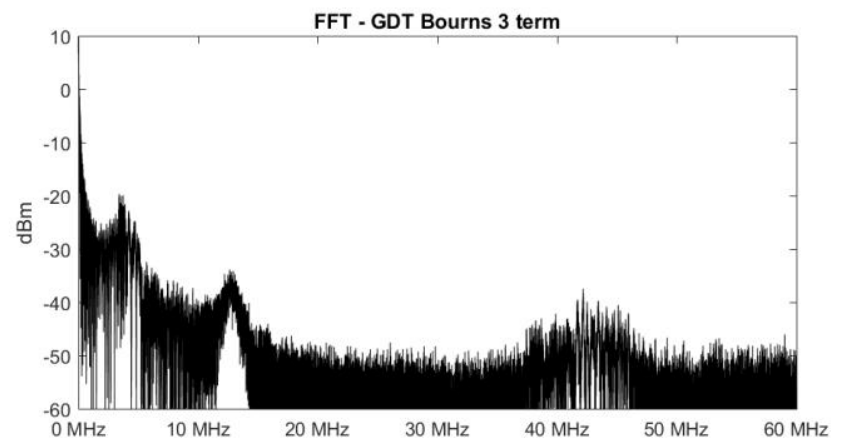

Table 1. List of components used for the construction of the suppressor circuit

\begin{tabular}{|l|l|l|}
\hline & \multicolumn{1}{|c|}{ Coil } & \multicolumn{1}{c|}{ Capacitors } \\
\hline LC & \multirow{3}{*}{ Würth 744711015 } & Würth FTXX 680nF \\
LC small & & Würth FTXX 68nF \\
\cline { 3 - 3 } LC middle & & Würth FTXX 15nF \\
\hline
\end{tabular}

The first variant in figure 11 excels among the presented solutions in terms of significantly reduced voltage spikes.
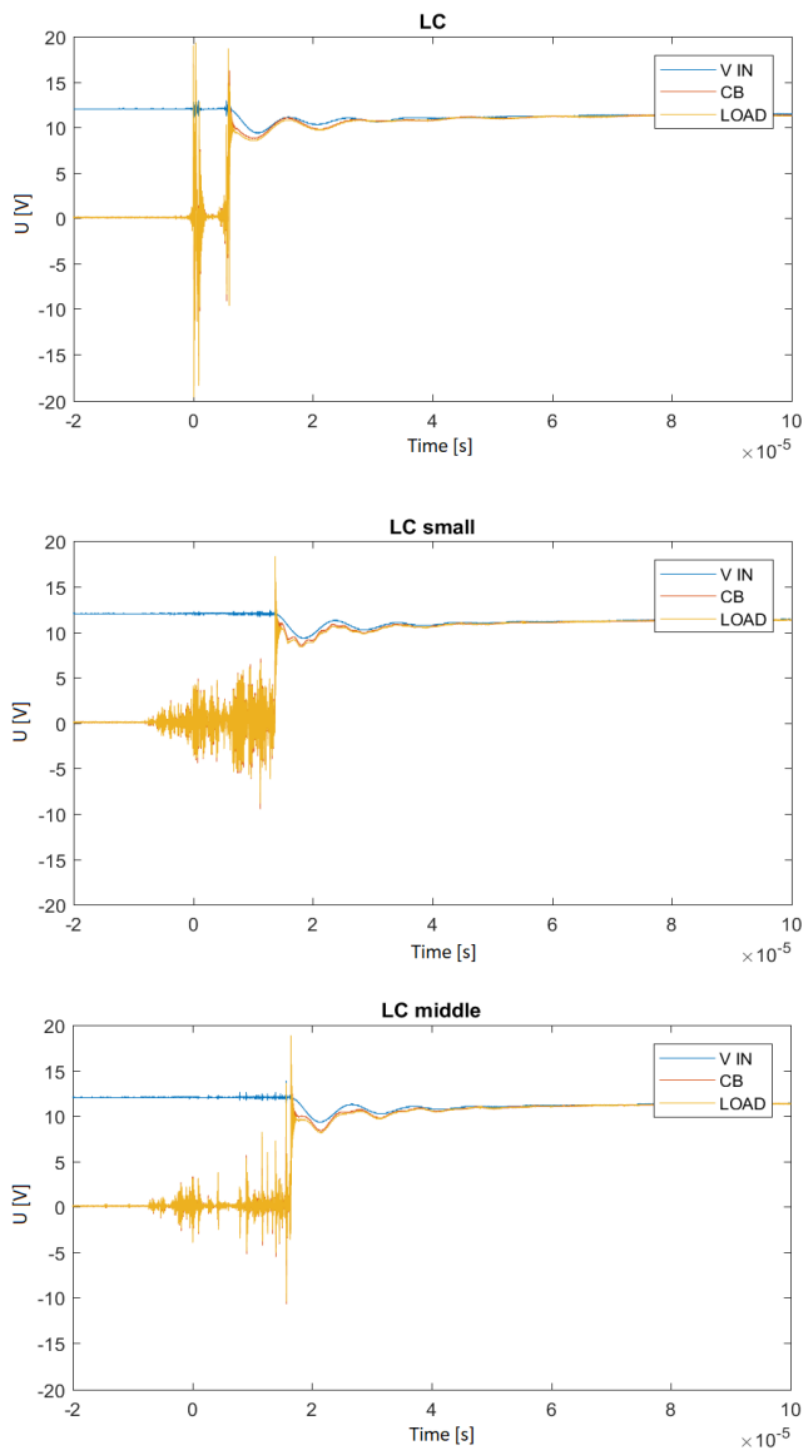

Fig. 11. Time waveforms of the observed disturbances with the use of LC filters

Fig. 8. Frequency analysis of the GDT + result without any filters

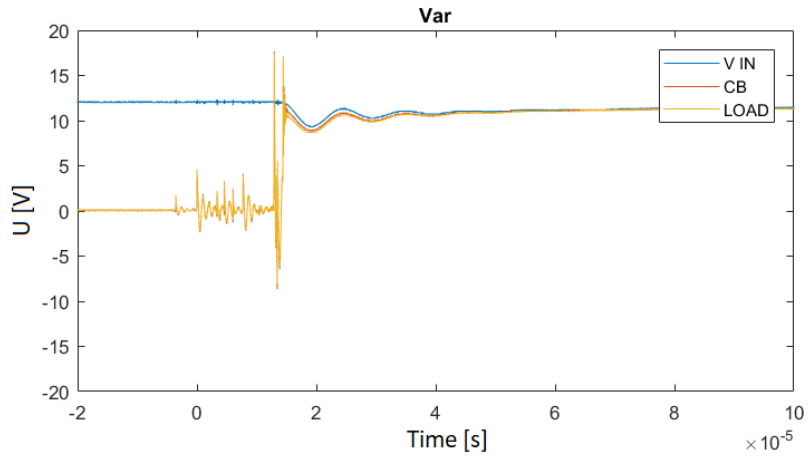

Fig. 9. Oscillograms - disturbance measurement with varistor 

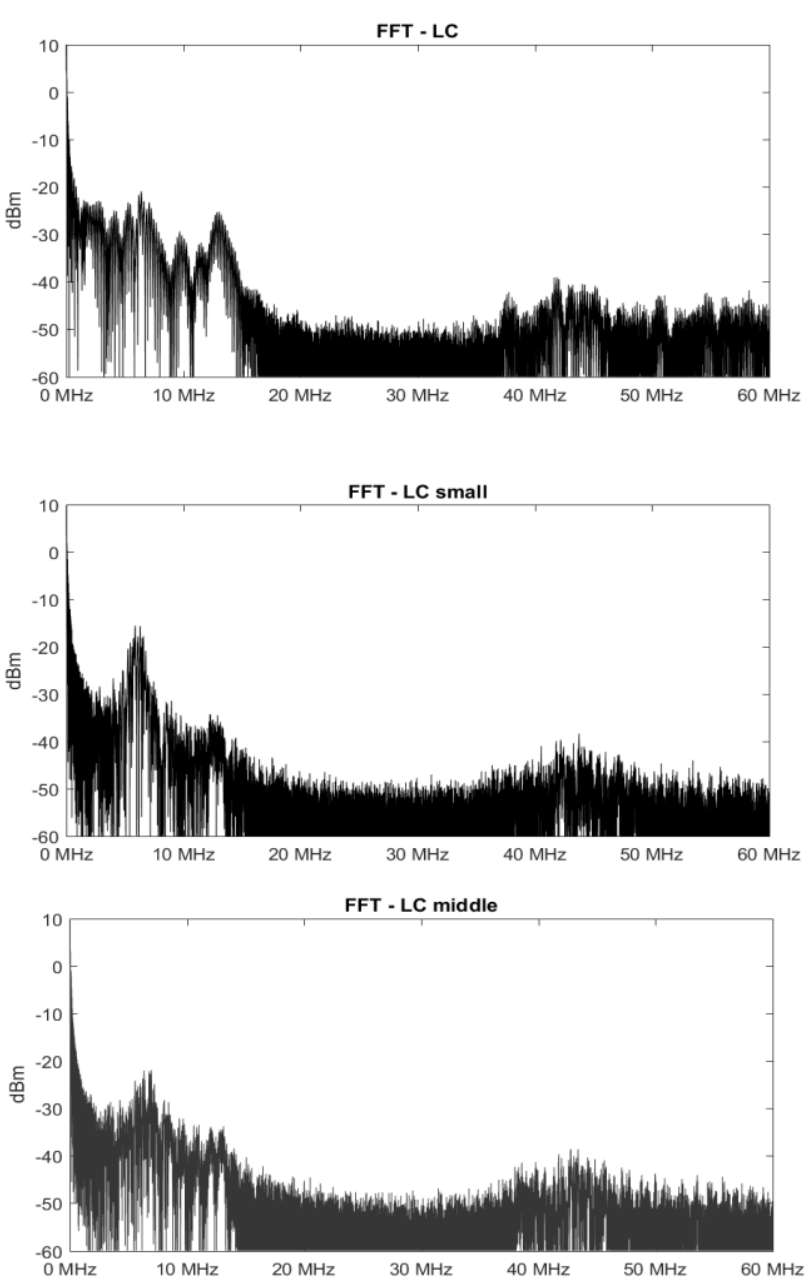

Fig. 12. LC filter frequency analysis

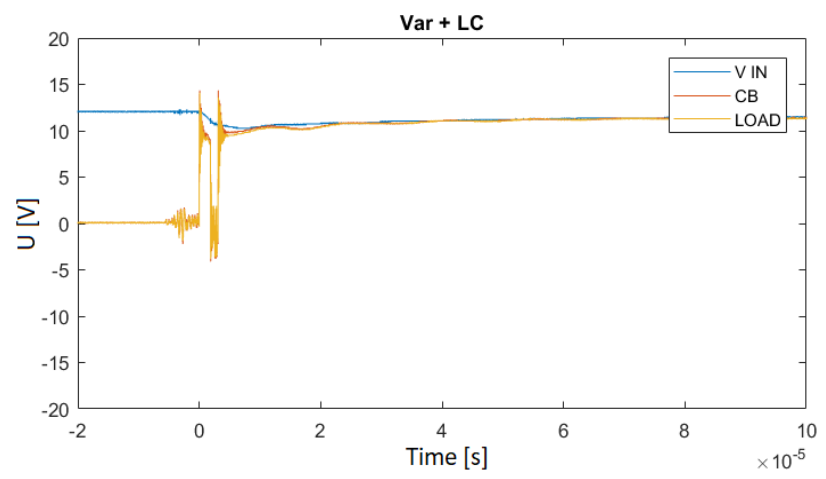

Fig. 13. Time waveforms of measured disturbances - hybrid solution

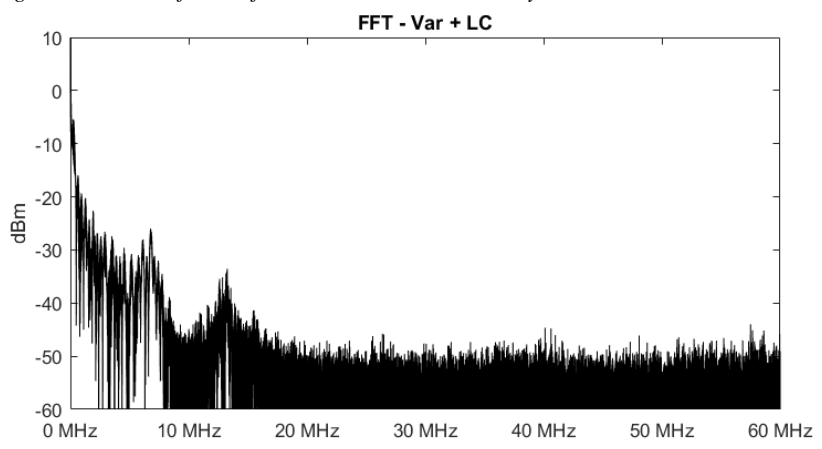

Fig. 14. Frequency analysis of the proposed solutions
The analysis in the frequency domain confirms the observation - the noise was significantly reduced, but the applied filtering circuitry did not achieve the voltage spikes reduction. In an attempt to remove these disturbances, it was decided to attach a previously tested varistor in parallel to the filter. The measurement results are presented in the waveforms in the Fig. 13 and Fig. 14.

The use of an LC filter and a varistor has given the best results so far - a significant reduction of the series of impulses and therefore a significant reduction of the wideband noise. The solution can be successfully mounted in a DIN housing (like a circuit breaker). Installation of such filter may increase the number of on-off cycles (increase mean time between failures) of such the commutator and enables safe analysis of the cycle of switching or disconnection. When the solution is applied to three-phase commutators, facilitate the analysis of commutation between channels without affecting the rising edge of the voltage. For sensitive electronic devices that will be on the load side of the commutator, the disturbance level generated by the commutator + varistor filter may still be too high, so it was decided to investigate further elements to reduce disturbance.

Due to the occurrence of suspected common mode disturbances, a solution that attenuates common-mode disturbances with a current-compensated choke was tested, a variant with added $\mathrm{X}$ capacitors, that created a filter for differential type disturbances and then an extended second variant with $\mathrm{Y}$ capacitors. These solutions enable to further reduction of common-mode disturbances creating a full first stage filter (see Fig. $17+$ Table 2).

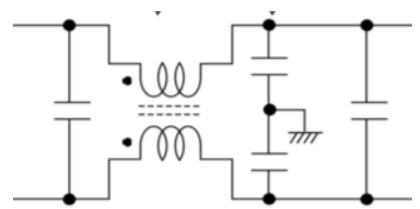

Fig. 17. Filter schematic

The time waveforms from the measurements of the constructed filters are shown on Fig. 18.
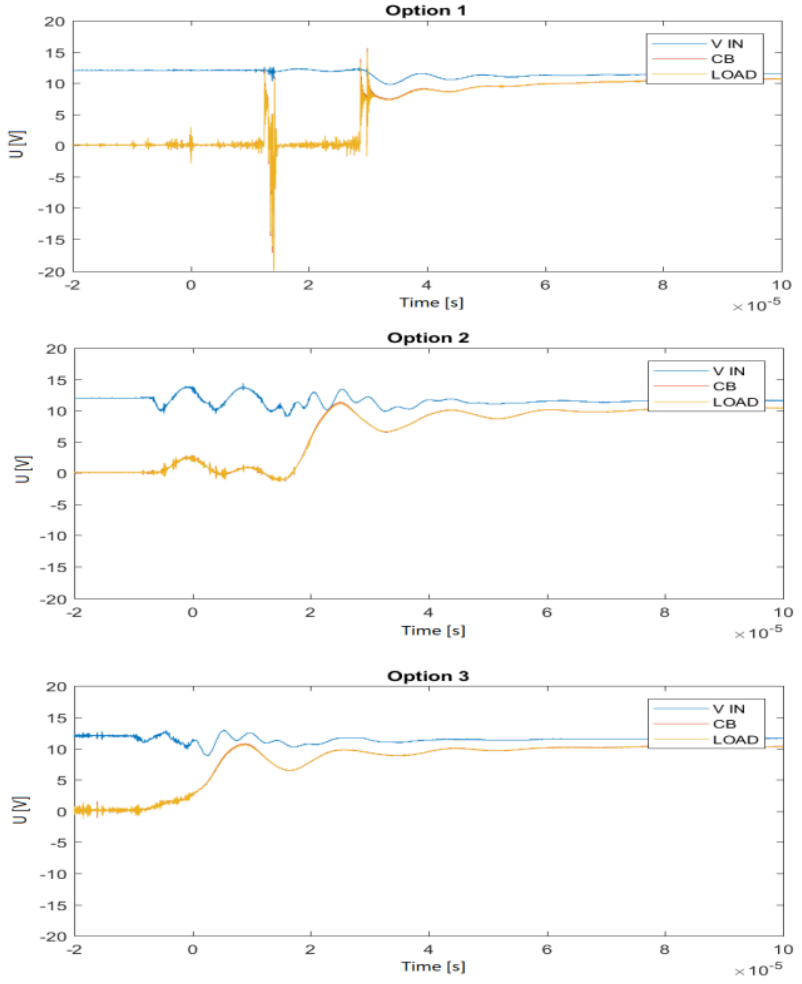

Fig. 18. Time analysis of the constructed filters 
Table 2. Components used to create the filter

\begin{tabular}{|l|l|l|}
\hline \multicolumn{1}{|c|}{ Option 1 } & \multicolumn{1}{c|}{ Option 2 } & \multicolumn{1}{c|}{ Option 3 } \\
\hline- & - & Würth CSSA 2.2nF \\
\hline- & Würth FTXX 680nF & Würth FTXX 680nF \\
\hline CMC Würth & CMC Würth & CMC Würth \\
7448251201 & 7448251201 & 7448251201 \\
\hline
\end{tabular}
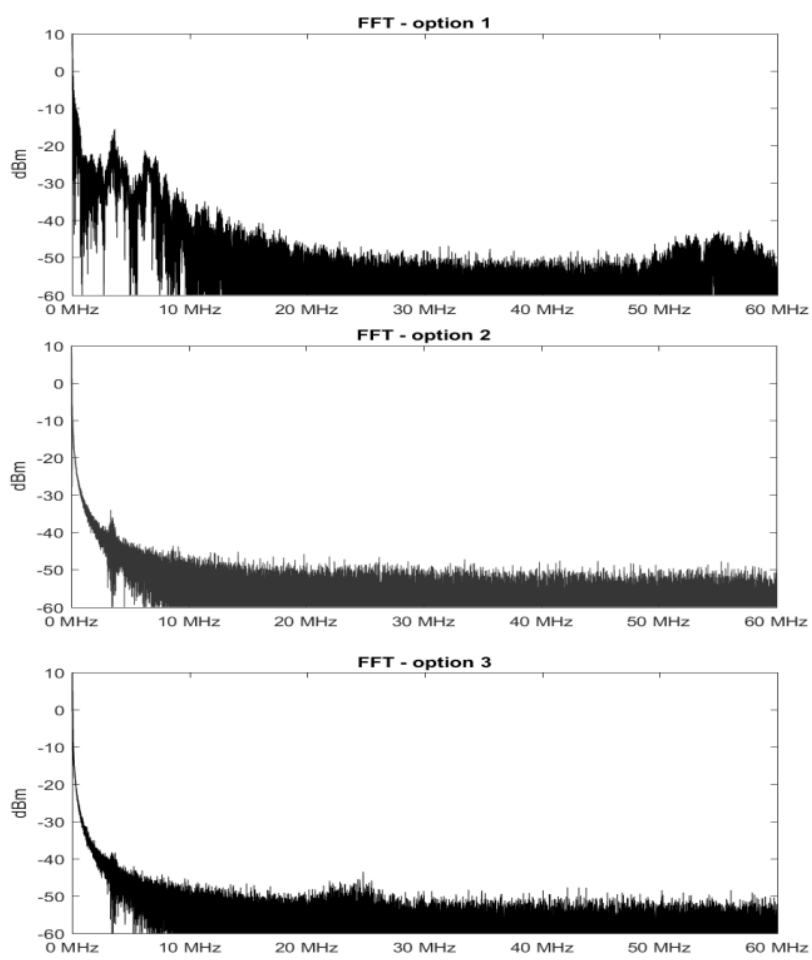

Fig. 19. Frequency domain analysis of constructed filters

The measurements show a significant reduction in the disturbance in all cases. The first option reduced the voltage impulses energy. The wideband noise, in spite of significant reduction, can still cause falsification of results of switch-on time measurements or can constitute a risk for sensitive electronic devices. For options 2 and 3, the disturbance was suppressed. Adding Y-type capacitors to the circuit reduced oscillations and noise at the moment of commutation. However adding capacitance extended the rising edge duration. This should be taken into account when analyzing the circuit.

For the case where a change in the slope of switching is not desired, a filter was constructed based on the current-compensated choke analyzed and the varistor tested earlier. Measurement results are presented on Fig. 20 and 21.

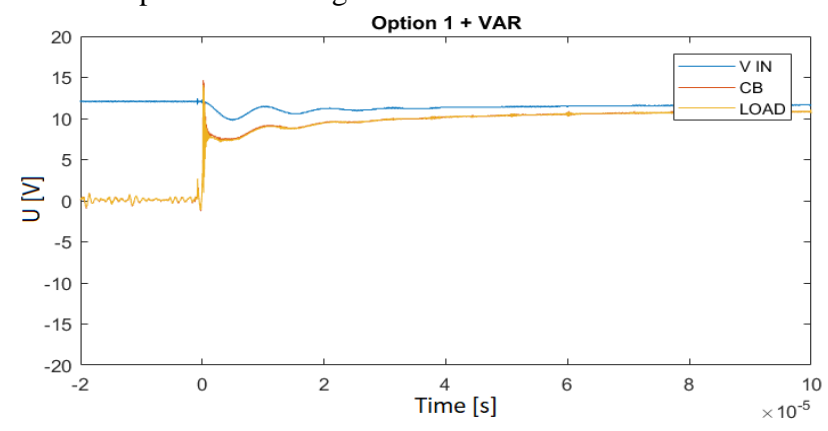

Fig. 20. Analysis of a solution using a combination of CMC and varistor

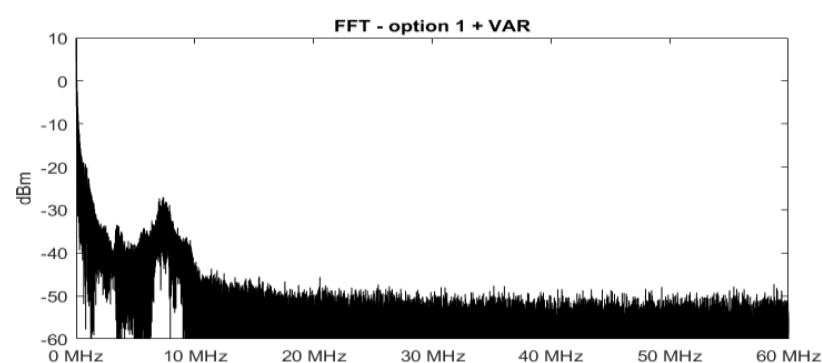

Fig. 21. FFT spectrum analysis of the CMC+VAR solution

The fluctuations have been greatly suppressed (compare graphs on Fig. 21), and only a small part remains, with a peak at 7.4 MHz. There was no significant change in the slope of the voltage at commutation, so the presented solution is more advantageous in this respect, and the filter circuit - less complicated. The filter built from a current-compensated choke with $\mathrm{X}$ and $\mathrm{Y}$ type capacitors has its equivalent in the integrated version, in a metal casing. For this reason, two filters was tested the single stage and two stage from Würth Elektronik, with the p/n, respectively: 810911010 and 810913020 . The measurement results are given on Fig. 22 and 23.
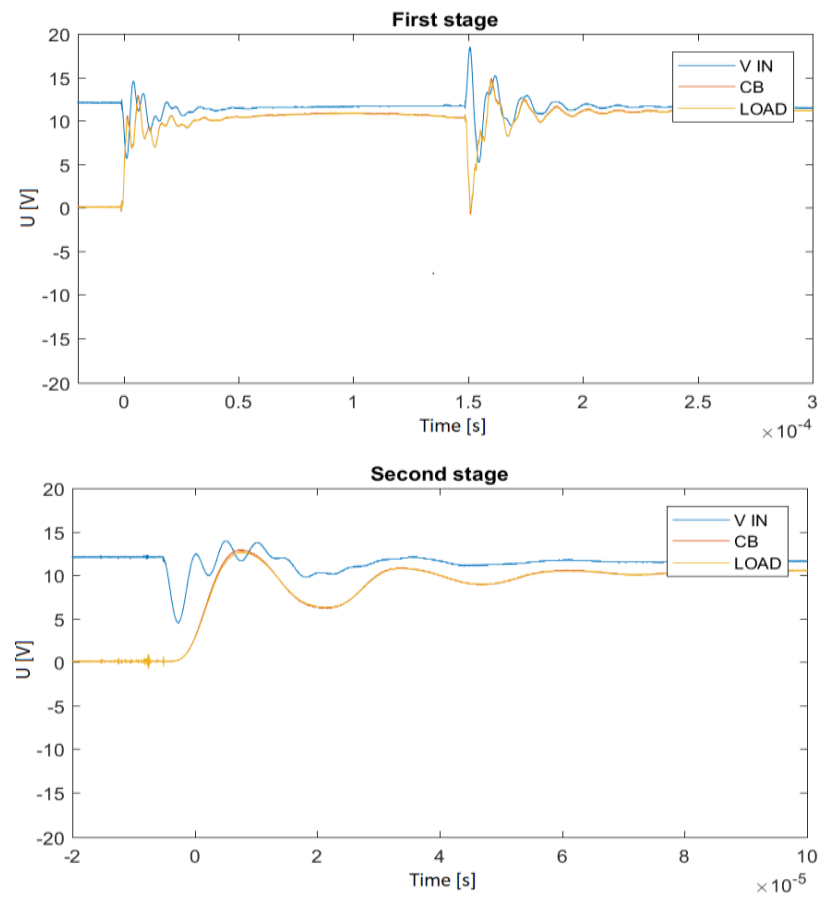

Fig. 22. Time analysis of integrated filters from Würth Elektronik

Filters noticeably reduced the disturbances level. On the oscillogram of the first option, a repeated oscillation was observed, which occurred each time the commutator was switched on. One of the possibilities is the filter resonance. In the second case, the oscillation prolongation was observed. Both cases have a softened voltage slope, however not as much as in the variant on discrete elements soldered to the PCB. One of the reasons for this situation is the use of a metal casing to enclose the filter structure. The other is filling the empty space with a special glue, which affects the filter elements characteristics, especially the currentcompensated choke. The mentioned choke can change its parameters even under the influence of the force applied to its core. 

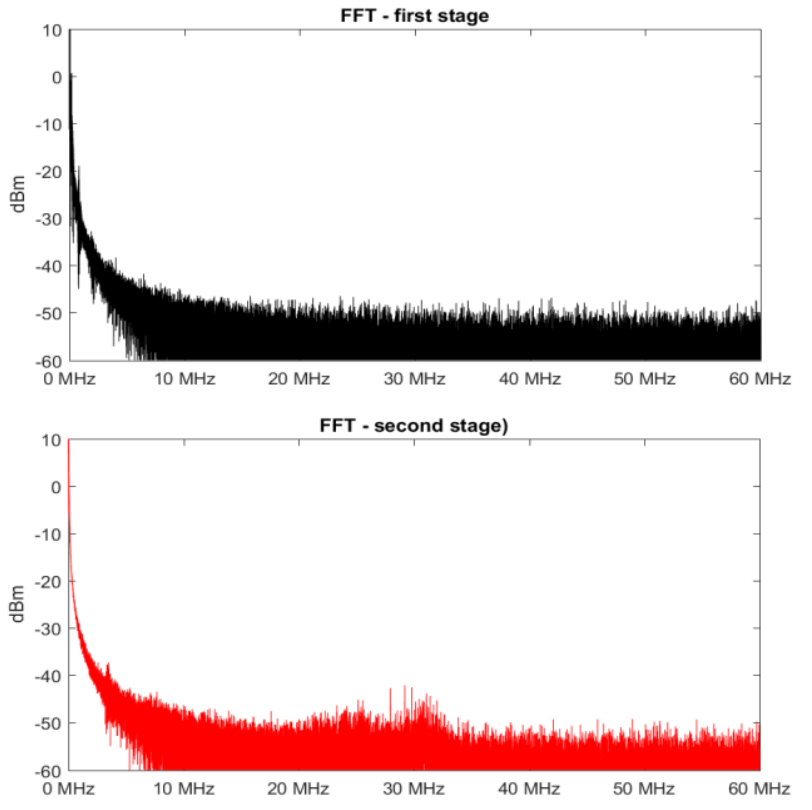

Fig. 23. Frequency analysis of integrated filters from Würth Elektronik

\section{Conclusion}

The measurements confirmed the effectiveness of the proposed fast, reliable and portable measurement method. The research performed has shown that commutators are a source of electromagnetic disturbances. Moreover, the disturbance level can be high enough to interfere with devices that do not have adequate protection in the coupling path protection form or other protective components. The commutation process is one of the most important moments when the disturbance is emitted into a circuit. After the switching process is completed, there is no emission of disturbances coming from the commutator due to the characteristic internal circuit breaker construction, which, after the switching process is completed, leaves the contacts stationary and protects them against uncontrolled disconnection. It is therefore preferable to use this method over a portable spectrum analyzer. The method, together with selected passive components, can be used to measure multi-channel circuit breakers, where correctly set switching times between channels are important.

The analyses of circuit breakers conducted as part of the study, using the bench built and using passive components, made it possible to identify the types of disturbance. The dominant disturbance is the differential type with a significant amount of common mode noise as well. Relevant differences in emission levels were observed, depending on the power supply circuit used. As expected, an increased disturbance level was observed with the DC supply, while lower values were observed with the AC supply. In the third point, systems were proposed and tested to reduce the disturbances emitted by a commutator with B characteristics.

Among the solutions reviewed, there are at least three most effective filters: LC with a varistor connected in parallel, a current-compensated choke with a varistor, and an integrated filter (or its equivalent on a printed circuit board, such as variant 3 with a current-compensated choke). The choice of solution is determined by the amount of space available to install the solution, the budget allocated for disturbance elimination and the objective the installer or user wants to achieve. If the intention is to protect the commutator, the first-mentioned variant should be chosen, which enables elimination of disturbances, which results in more stable commutation. If the purpose is to attenuate disturbances for measurements of switching times of commutator, e.g. with multi-position switches, the second solution should be chosen, or LC filter with varistor should be multiplied, and if the purpose is a complete elimination of disturbances from the system, irrespective of voltage edge on the commutator, it is necessary to install either integrated filter, preferably of two stage type, or a filter built from elements from presented option 3 (capacitors $X$, $\mathrm{Y}$, and current-compensated choke).

\section{References}

[1] Bander T., Gerfer A., Bernhard R., Heinz Z.: Trilogy of Magnetics. Adolf Würth GmbH \& Co. KG, Waldenburg 2019.

[2] Clayton R. P.: Introduction to Electromagnetic Compatibility. Wiley 2006.

[3] Gerfer A. et al.: Trilogy of Connectors. Adolf Würth GmbH \& Co. KG, Waldenburg 2015

[4] Ibrahim, A. I. et al.: A Knowledge Base for Switching Surge Transients. International Conference on Power Systems Transients (IPST), 2005.

[5] Martinez J. A., Natarajan R., Camm E.: Comparison of statistical switching results using Gaussian, uniform and systematic switching approaches. Powe Engineering Society Summer Meeting, 2002.

[6] Mroczka J.: The cognitive process in metrology. Measurement 46, 2013, 2896-2907.

[7] Ott H. W.: Electromagnetic Compatibility Engineering. Wiley, 2009.

[8] Phaniraj V., Phadke A. G.: Modelling of circuit breakers in the electromagnetic transients program. IEEE Transaction on Power System 3(2), 1988, 799-805.

[9] Popov M. et al.: Investigation of the Circuit Breaker Reignition Overvoltages Caused by No-load Transformer Switching Surges. European Transactions on Electrical Power 11(6), 2001, 413-422.

[10] Rachard H. et al.: Numerical study of coupled electromagnetic and aerothermodynamic phenomena in a circuit breaker electric arc. International Journal of Heat and Mass Transfer 42(9), 1999, 1723-1734.

[11] Uglešić I. et al.: Transients Caused by Uncontrolled and Controlled Switching of Circuit Breaker. The International Symposium on High-Voltage Technique "Höfler's Days", Portoroz, Slovenia, 2013.

[12] Wen W. et al.: Transient Current Interruption Characteristics of a Novel Mechanical DC Circuit Breaker. IEEE Transactions on Power Electronics 33, 2018, 9424-9431.

[13] Legrand TX3 B16 691223-Model Datasheet. Available online: https://www.tme.eu/Document/957dfb2ffaa80d87ef4a3a3f44f22512/LEGRAND -TX.pdf (accessed on 8.11.2021)

[14] PicoScope 3000D Series Data Sheet Available online: https://www.picotech.com/download/manuals/picoscope-3000d-seriesoscilloscopes-data-sheet.pdf (accessed on 8.11.2021).

[15] Portable spectrum analyzer Aaronia Spectran 6 Datasheet. Available online https://aaronia.com/download/14538/ (accessed on 13.06.2021).

[16] TA189 Current Clamp User's Guide. Available online: https://www.picotech.com/download/manuals/ta189-30a-current-clamp-usersguide.pdf (accessed on 8.11.2021).

\section{M.Sc. Eng. Patryk Dariusz Wąsik}

e-mail: patryk.wasik@pwr.edu.pl

Patryk Dariusz Wasik received the M.Sc. degree from WUST, Poland, in 2019. He is currently an assistant on Chair of Electronic and Photonic Metrology, Wroclaw University of Science and Technology, Poland His current research focuses on Electromagnetic Interferences in HF connectors.

http://orcid.org/0000-0002-1927-4111 otrzymano/received: 8.11 .2021 